\title{
Iron Deficiency Anemia as The Only Manifestation of Colon Cancer in Male Patient: A Case Report
}

\author{
Wulyo Rajabto*, Pandu Tridana Sakti*, Andi Putra Kevinsyah* \\ ${ }^{*}$ Division of Hematology-medical Oncology, Department of Internal Medicine, \\ Faculty of Medicine, Universitas Indonesia/Dr. Cipto \\ Mangunkusumo General National Hospital, Jakarta
}

\begin{abstract}
Corresponding author:
Andi Putra Kevinsyah. Division of Hematology-medical Oncology, Department of Internal Medicine, Dr. Cipto Mangunkusumo General National Hospital. Jl. Diponegoro No. 71 Jakarta, Indonesia. Phone: +62-21-3162497; facsimile:+62-21-3926286E-mail:kevinsyah@outlook.com
\end{abstract}

\begin{abstract}
Iron deficiency anemia can be the first manifestation of colon cancer. However, iron deficiency anemia is also common in other benign conditions, which may cause a longer delay for referral decisions to get a definitive diagnosis. This is a case of 40-year-old male patient who had only iron deficiency anemia as a manifestation of colon cancer. Colonoscopy revealed intraluminal mass in transverse colon. After resection of the tumor, histopathology showed well-differentiated mucinous adenocarcinoma, invasion of sub-serous, and one node positive (pT3pNIpM0). After resection, we administered XELOX as adjuvant chemotherapy every 3 weeks for 8 cycles.
\end{abstract}

Keywords: Iron deficiency anemia, colon cancer, XELOX chemotherapy

\section{ABSTRAK}

Anemia defisiensi besi dapat menjadi satu-satunya manifestasi klinis pada pasien dengan kanker kolon. Tetapi, anemia defisiensi besi juga merupakan keadaan yang umum terjadi dan sering muncul pada keadaan selain keganasan, sehingga dapat menyebabkan penundaan untuk merujuk pasien yang sebenarnya memerlukan pemeriksaan lebih lanjut untuk penegakan diagnosis definitif. Kami melaporkan sebuah kasus pasien laki-laki berusia 40 tahun yang menderita kanker kolon tetapi manifestasi klinis satu-satunya yang muncul hanyalah anemia defisiensi besi. Pemeriksaan kolonoskopi menunjukkan massa intraluminal di colon transversus. Setelah dilakukan reseksi tumor, pemeriksaan histopatologi menunjukkan adenokarsinoma musinosa diferensiasi baik, menginvasi subserosa, dengan satu kelenjar getah bening positif ditemukan anak sebar tumor (pT3pN1pM0). Setelah dilakukan reseksi, kami memberikan kemoterapi adjuvant XELOX setiap 3 minggu untuk 8 siklus

Kata kunci: anemia defisiensi besi, kanker kolon, kemoterapi XELOX

\section{INTRODUCTION}

Colon cancer is the $3^{\text {rd }}$ most common cancer which is one of the leading causes of cancer-related deaths worldwide. ${ }^{1}$ Incidence of colorectal cancer in Indonesia was 12.8 per 100,000 adult population, with mortality $9.5 \%$ of all cancer cases and made it the third most common malignant neoplasm in Indonesia. ${ }^{2}$
Iron deficiency anemia has long been recognized as a clinical manifestation of cancer. It is present in 5-10\% of colonic carcinoma in United Kingdom. ${ }^{3}$ One study showed anemia patients with iron deficiency anemia as their presenting feature of cancer had worse staging and mortality. ${ }^{4}$

Iron deficiency anemia can be the first manifestation of right-sided colon cancer. There is an impression 
that because this presentation is nonspecific it may be associated with a longer delay from referral to diagnosis compared with those patients with symptoms of change in bowel habit and/or rectal bleeding caused by more distal colorectal cancer. ${ }^{5}$

\section{CASE ILLUSTRATION}

A 40-year-old male patient, complaining of fatigue. He denied history of bloody stool. There were no complaints of abdominal pain, distension, nausea,

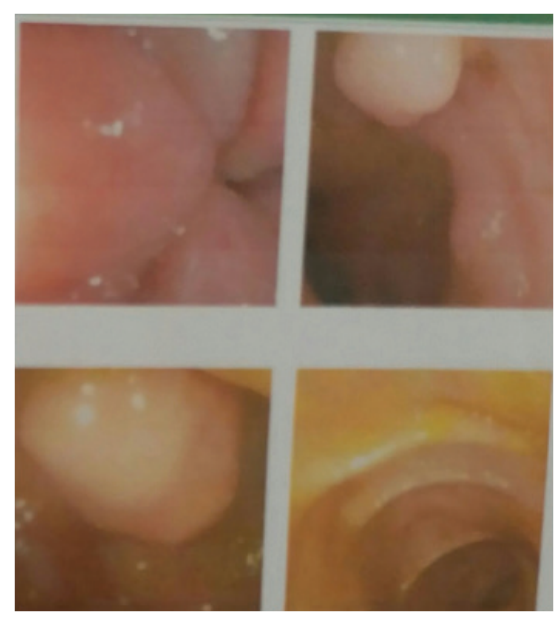

Figure 1. Colonoscopy showing polyps in rectum and descendant colon

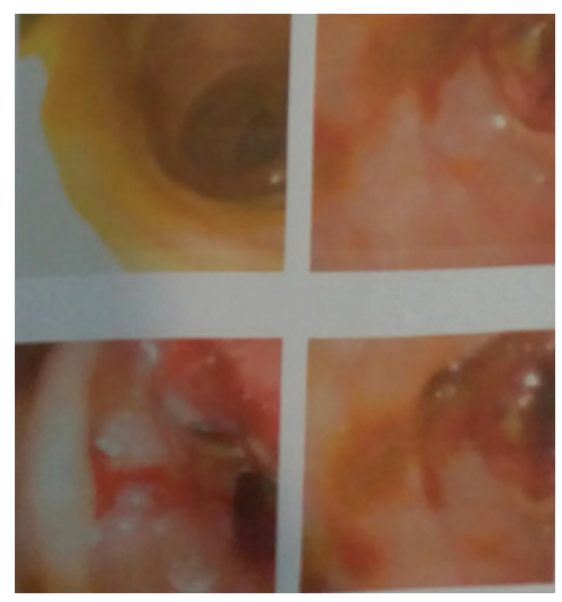

Figure 2. Colonoscopy showing intraluminal mass in transverse colon

vomiting, weight loss, constipation or diarrhea. There was no family history of colorectal cancer. The physical examination found pale bilateral conjunctiva, with no other abnormalities.

Laboratory tests showed hypochromic microcytic anemia with hemoglobin level of $7.3 \mathrm{~g} / \mathrm{dL}$ and hematocrit $26 \%$. The patient had been evaluated in primary health care for anemia for 6 months before referral to our hospital. Serum iron level was low 10 $\mathrm{ug} / \mathrm{dL}$, high level of total iron binding capacity 355.6
ug/dL, low ferritin level $1.89 \mathrm{ng} / \mathrm{mL}$, and normal CEA.

Colonoscopy revealed polyps in rectum and descendant colon (Figure 1.), and vegetating intraluminal mass occupying $90 \%$ of the transverse colon cavity which causes obstruction (Figure 2.). Histopathology samples were taken from colonoscopy, and showed tubular adenoma, well-differentiated adenocarcinoma.

Computed tomography (CT) of the abdomen was performed and identified intraluminal mass in transverse colon $11 \times 3.08 \mathrm{~cm}$ with enhancement after contrast administration; thickening of the ascendant colon $11.16 \times 3 \mathrm{~cm}$.

The digestive surgeon performed laparotomy and hemicolectomy dextra. Histopathology finding from hemicolectomy sample showed well-differentiated mucinous adenocarcinoma, invasion into sub-serous, and one node positive for tumor from seven nodes collected (T3N1M0).

We administered the adjuvant chemotherapy XELOX (Capecitabine-Oxaliplatin) every 3 weeks for 8 cycles. Side effects of chemotherapy were peripheral neuropathy, mild leukopenia, and thrombocytopenia. Five years after adjuvant chemotherapy, there were no relapse and no iron deficiency anemia.

\section{DISCUSSION}

Iron deficiency anemia, which was the only clinical manifestation in our patient who had colon cancer, must be a sign for a physician to evaluate long episode of anemia with unknown causes. A retrospective study showed $6.3 \%$ patients with iron deficiency anemia (hemoglobin $<11 \mathrm{~g} / \mathrm{dL}$ in males and $<10 \mathrm{~g} / \mathrm{dL}$ in postmenopausal females, mean corpuscular volume $<78 \mathrm{fl}$ and/or serum ferritin $<12 \mathrm{ng} / \mathrm{ml}$ ) had colon cancer, in which male patients had more proportion than female. Right colon is the most commonly affected part ( 8 to 9 cases). ${ }^{5}$

A retrospective analysis of two institutions showed that the most common signs and symptoms of younger colorectal cancer patients (under 50-year) were rectal bleeding $(57 \%)$, abdominal pain $(31 \%)$, change in bowel habits $(21 \%)$, weight loss $(11 \%)$, and anemia $(11 \%)$. Most patients were diagnosed with $3^{\text {rd }}$ stage of disease (39\%) when coming to the hospital. ${ }^{6}$ In the other study of 280 consecutive symptomatic patients with colorectal cancer who come to primary care physicians, presented with iron deficiency anemia $(24,6 \%)$, besides abdominal pain $(79,6 \%)$, bloating $(59,6 \%)$, constipation $(47,8 \%)$, diarrhea $(30,3 \%)$. Iron deficiency anemia and age $>50$-year were the only 
independent variables associated with colorectal cancer $\left(\mathrm{OR}=8.8\right.$ and 9.0, respectively). ${ }^{7}$

A nationwide population-based study conducted by Teng et al in Taiwan, showed that colon cancer patients who had iron deficiency anemia during 18 months or earlier preceding the diagnosis of colon cancer, have poorer prognosis compared to those without iron deficiency anemia (Median OS of 4.6 years versus 5.7 years), and that those patients with iron deficiency anemia who had earlier colonoscopy, thus earlier diagnosis of colon cancer, were associated with better prognosis compared to those with delayed colonoscopy (Colonoscopy $\leq 30$ days, $31-90$, and $\geq$ 91 days after IDA diagnosis showed median overall survival times of $5.79,4.43$, and 4.04 years). ${ }^{10}$ This shows that the manifestation of iron deficiency anemia should always remind us to consider colon cancer in the differential diagnosis, and that early detection of colon cancer will bring better prognosis for the patient.

Males referred with iron deficiency anemia have a significant risk of having colon cancer. The recurrent abnormal hemoglobin results which indicated iron deficiency can be used to guide the physician in primary health care in deciding the differential diagnosis of colorectal cancer and provide for referral decision.

\section{REFERENCES}

1. Siegel R, Ma J, Zou Z, et al: Cancer statistics, 2014. CA Cancer J Clin. 2014;64:9-29

2. Indonesia National Cancer Prevention Committee. Colorectal Cancer: National Guidelines for Medical Services. The Health Ministry of the Republic of Indonesia 2017:1.

3. Goddard AF, James MW, Mclntyre AS, et al. Guidelines for the Management of Iron Deficiency Anaemia. Gut 2011;60:1309-16.

4. Hamilton W, Lancashire R, Sharp D, et al. The Importance of Anaemia in Diagnosing Colorectal Cancer: A Case-Control Study Using Electronic Primary Care Records. British Journal of Cancer 2008;98:323-27.

5. Raje D, Mukhtar H, Oshowo A, et al. What Proportion of Patients Referred to Secondary Care with Iron Deficiency Anemia have Colon Cancer? Dis Colon Rectum 2007;50:12114.

6. Myers EA, Feingold DL, Forde KA, et al. Colorectal Cancer in Patients Under 50 Years of Age: A Retrospective Analysis of Two Institutions Experience. World J Gastroenterol 2013;19:5651-5657.

7. Panzuto F, Chiriatti A, Bevilacqua S, et al. Symptom-Based Approach to Colorectal Cancer: Survey of Primary Care Physicians in Italy. Dig Liver Dis 2003;35:869-75.

8. Hamilton W, Round A, Sharp D, et al. Clinical Features of Colorectal Cancer Before Diagnosis: A Population-Based Case-Control Study. British Journal of Cancer 2005;93:399405.
9. Astin M, Griffin T, Neal RD, et al. The Diagnostic Value of Symptoms for Colorectal Cancer in Primary Care: A Systematic Review. British Journal of General Practice. 2011:e231-43.

10. Teng CLJ, Yu JT, Chen YH, Lin CH, Hwang WL. Early colonoscopy confers survival benefits on colon cancer patients with pre-existing iron deficiency anemia: A nationwide population-based study. PLoS One 2014;9:1 